\title{
Aktivitas Antioksidan dan Total Polisakarida Ekstrak Rumput Laut Merah, Hijau dan Coklat dari Pantai Jangkar Situbondo
}

(Antioxidant Activity and Total Polysaccharide of Red, Green and Brown Seaweed from Jangkar Situbondo Coastal)

Didin Erma Indahyani', Depi Praharani2 ${ }^{2}$, Izzata Barid', Ari Tri Wanodyo Handayani ${ }^{3}$

1 Bagian Biologi Oral, Fakultas Kedokteran Gigi, Universitas Jember

2 Bagian Periodonsia, Fakultas Kedokteran Gigi, Universitas Jember

3 Bagian Ilmu Kesehatan Gigi Masyarakat, Fakultas Kedokteran Gigi, Universitas Jember

\section{Abstrak}

Rumput laut mempunyai aktivitas antioksidan yang tinggi. Kandungan polisakarida dan bioaktif lainnya pada rumput laut berfungsi menghambat radikal bebas. Perbedaan aktivitas antioksidan dan komposisi polisakaridanya dipengaruhi oleh spesiesnya (rumput laut merah, hijau dan coklat), kondisi geografis, iklim serta metode ekstraksi meliputi fase solid dan fase gerak serta temperature dan lamanya waktu ekstraksi. Tujuan penelitian ini adalah untuk mengetahui aktivitas antioksidan dan total polisakarida pada ekstrak rumput laut merah, hijau dan coklat dari pantai Jangkar Situbondo. Metode. Penelitian dilakukan pada rumput laut merah, hijau dan coklat yang diekstraksi dengan etanol dan air untuk menentukan polisakarida total. Analisis antioksidan menggunakan metode 2,2-diphenyl1picrylhydrazyl (DPPH) radikal. Total polisakarida dan aktivitas antioksidan diamati secara statistik menggunakan ANOVA dua arah. Hasil penelitian ini menunjukkan bahwa kandungan polisakarida dalam ekstrak air rumput laut secara signifikan lebih tinggi daripada ekstrak etanol, terutama pada rumput laut coklat. Ekstrak air rumput laut menunjukkan aktivitas antioksidan yang lebih tinggi daripada ekstrak etanol. Aktivitas antioksidan rumput laut coklat secara signifikan lebih tinggi daripada rumput laut hijau dan merah. Kesimpulan. Rumput laut memiliki aktivitas antioksidan yang tinggi dalam ekstrak air. Rumput laut coklat mengandung polisakarida yang tinggi dan memiliki aktivitas antioksidan yang tinggi.

Kata kunci : antioksidan, ekstraksi, polisakarida, rumput laut

\section{Abstract}

The antioxidant activity and polysaccharide composition of seaweed is influenced by species (red, green and brown seaweed), geographical conditions, extraction methods, solvents, temperature and the length of time of extraction. The purpose of this study was to known the total polysaccharide and antioxidant activity in red, green and brown seaweed extracts from Jangkar Situbondo beach. Method. The study was conducted on red, green and brown seaweed extracted with ethanol and water to determine total polysaccharides. Antioxidant analysis uses the method 2,2-diphenyl 1-picrylhydrazyl (DPPH) radical. Total polysaccharide and antioxidant activity were observed statistically using two-way ANOVA. The results of this study show that the polysaccharide content in seaweed water extract was significantly higher than ethanol extract, especially in brown seaweed. Seaweed water extracts showed higher antioxidant activity than ethanol extracts. The antioxidant activity of brown seaweed was significantly higher than that of green and red seaweed. Conclusion. Seaweeds have high antioxidant activity in water extracts. Brown seaweed water extract contains high polysaccharides than green and red seaweed. Antioxidant activity in brown seaweed is also higher than in green and red seaweed

Keywords : antioxidant, extraction, polysaccharide, seaweed

Korespondensi (correspondence) : Didin Erma Indayani. Bagian Biologi Oral, Fakultas Kedokteran Gigi, Universitas Jember. Email : didinerma.fkg@unej.ac.id

Rumput laut dikenal kaya polisakarida, mineral dan juga vitamin. Rumput laut juga mengandung substansi bioactive lain misalnya proteins, lemak, polifenol yang berfunsgi sebagai anti bakteri, antivirus dll.' Secara kimia polisakarida rumput laut merupakan gabungan beberapa monosakarida oleh adanya ikatan glikosidik. Heteropolysaccharides (glycans) jika tipe monosaccharidesnya berbeda, atau homopolysaccharides, jika hanya terdiri dari satu tipe unit gula. Polisakarida rumput laut dapat dikelompokkan menjadi tersulfasi dan non-sulfat. Polisakarida tersulfasi (Sulfonated polysaccharides) adalah fucoidans, agar, karagenan dan ulvans, sedangkan polisakarida non-sulfat adalah alginat. Variasi strukturalnya memberikan perbedaan jenis polisakarida. ${ }^{23}$ Polisakarida tersulfasi menunujukan aktivitas antioksidan karena sifat fisikokimianya misalnya berat molekul, kandungan -OSO3H dan polifenol. 4 Polisakarida rumput laut terdapat di dalam dinding sel yang jumlah dan struktur kimianya bervariasi tergantung pada spesies rumput lautnya. Ada tiga tipe polisakarida tersebut yaitu yang banyak ditemukan di rumput laut coklat adalah fucan, di rumput laut hijau rhamnans tersulfasi dan ulvan sedangkan dirumput laut merah adalah galaktan dan karagenan. Masing masing mempunyai potensi untuk aplikasi kimia, makanan, pertanian, dan farmasi. ${ }^{5}$ Polisakarida ini umumnya diekstraksi dengan air panas, yang merupakan metode paling populer dan mudah. Akan tetapi metode ini memakan waktu, suhu harus tinggi, dan efisiensi ekstraksi rendah. Secara umum, metode ekstraksi melibatkan penghilangan zat yang mengganggu (seperti senyawa dengan berat molekul rendah, lipid dan zat warna dari 
rumput laut) dengan menggunakan campuran metanol / kloroform / air (4: 2: 1; v/ v/ v)5.6 Metode ekstraksi memberikan perubahan berkurangnya kandungan toksik atau bahan yang terakumulasi dari air oleh rumput laut.? Selain metode dan bahan ekstraksi, kandungan bioactive di dalam rumput laut juga dipengaruhi kondisi musiman dan wilayah geografis dan spesiesnya, perubahan lingkungan misalnya sinar, nutrient, kontaminan, salinitas air, ketersediaan CO2, $\mathrm{pH}$, temperature dan interaksi biotik. Polisakarida permukaan sel bertanggung jawab atas tingkat tinggi mineral dan elemen lainya karena retensi zat laut anorganik didalamnya. Rumput laut juga sebagai sumber potensial protein berkualitas tinggi, sehingga secara efektif digunakan sebagai suplemen langsung atau dapat digunakan untuk formulasi produk kesehatan lainnya seperti nutraceuticals. ${ }^{8}$ Potensi antioksidan rumput laut berkaitan dengan metode ekstraksi, yang akan mempengaruhi konsentrasinya. Metode ekstraksi itu termasuk pelarut, prosedur, suhu, waktu dan struktur matrik solidnya terutama ukuran partikel.9 Tujuan penelitian ini adalah untuk menganalisis kandungan polisakarida pada ekstraksi air dan etanol rumput laut merah, coklat dan hijau dan aktivitas antioksidannya

\section{METODE PENELITIAN}

\section{Persiapan Ekstraks Rumput Laut}

Sesuai dengan metodelo Rumput laut merah, coklat dan hijau yang sudah diindentifikasi spesiesnya (dilakukan di MIPA Biologi Universitas Jember), dilakukan ekstraksi di laboratorium Biologi Farmasi Universitas Jember. Rumput laut (merah, hijau dan coklat) segar masing masing disiapkan dan dicuci dengan air tawar, kemudian dikeringkan di bawah sinar matahari selama 5 hari. Dilakukan pengovenan pada suhu $60^{\circ} \mathrm{C}$ selama 3 jam, kemudian di haluskan dan diayak 30 mesh.

\section{Persiapan Ekstrak Air}

Lima puluh gram tepung rumput laut dihomogenasi dengan air distilasi. Ekstraknya di saring dengan cotton wool kemudian dengan filter paper Whatman No.1. Filtrat tersebut dilipolisasi menggunakan freeze dryer (Eyela FD-1) dan disimpan pada suhu $-10^{\circ} \mathrm{C}$ sampai digunakan.

\section{Persiapan Ekstrak Etanol}

Bubuk rumput laut $(100 \mathrm{~g})$, direndam dalam $100 \%$ etanol selama 1 minggu. Ekstrak difilter dengan Whatman No.1, dan diulang 3 kali. Semua filtrate dikumpulkan dan dikonsentrat untuk pengeringan pada rotary evaporator (Buchi R-200). Bahan ekstrak tersebut kemudian di simpan pada temperature kamar sampai digunakan.

\section{Ekstraksi Polisakarida Rumput Laut}

Tepung rumput laut yang telah dipersiapkan, di ekstrak dengan pelarut yang digunakan secara bertahap yaitu dengan air, air panas, $\mathrm{H}_{2} \mathrm{SO}_{4} \quad 0,05 \%$ dan $\mathrm{NaOH} 0,05 \%$. Campuran tepung dan pelarut didiamkan selama satu jam pada suhu $30^{\circ} \mathrm{C}$. Campuran kemudian disaring dengan kertas saring biasa, ampas yang diperoleh kemudian direndam kembali dengan air panas $\left(100^{\circ} \mathrm{C}\right)$ selama 1 jam, disaring kembali dan ampasnya direndam kembali dengan $\mathrm{H}_{2} \mathrm{SO}_{4} 0,05 \%$ selama satu jam pada suhu $100^{\circ} \mathrm{C}$. Campuran disaring kembali dengan menggunakan $\mathrm{NaOH} 0,05 \%$ selama 1 jam pada suhu $100^{\circ} \mathrm{C}$. Rendemen polisakarida dari setiap pelarut diperoleh dengan cara mendapatkan filtrat dari setiap hasil saringan dengan menggunakan etanol absolut dan air masing masing sebanyak 100 $\mathrm{ml}$ selama $24 \mathrm{jam}$. Setelah direndam filtrate kembali disaring dan endapan dikeringkan dan ditimbang.

\section{Analisis Antioksidan dengan Metode 2,2- Diphenyl1-Picrylhydrazyl (Dpph) Radical}

Analisis kapasitas antioksidan dilakukan dengan pengukuran DPPH sesuai metode Brand-Williams, et al, adalah sebagai berikut. Atom hidrogen atau kemampuan sumbangan elektron dari sampel dan standar diukur dari larutan metanol DPPH berwarna ungu muda. Lima microliter $(\mu \mathrm{L})$ dari masing masing sampel ekstrak (rumput laut merah, coklat dan hijau) ditambahkan 2,2-diphenyl1-picrylhydrazyl (DPPH) (Sigma, Steinheim, Germany) $0.094 \mathrm{mM}$ dalam methanol sampai mencapai $1 \mathrm{~mL}$. Aktivitas free radical scavenging menggunakan reaksi free radical DPPH dievaluasi dengan mengukur absorbansi pada $515 \mathrm{~nm}$ setelah 60 menit reaksi pada suhu $200 \mathrm{C}$ dalam spectrophotometer (Varian Cary 50-Bio, Victoria, Australia). Aktivitas antioksidan masing-masing sampel dinyatakan dengan persen penghambatan radikal bebas DPPH dihitung dengan rumus sebagai berikut dan Asam askorbat digunakan sebagai control. ${ }^{11}$ inhibisi $(\%)=\frac{\text { absorbansi blanko }- \text { absorbansi sampel }}{\text { absorbansi blanko }}$

\section{HASIL PENELITIAN}

Hasil identifikasi rumput laut merah, hijau dan coklat yang dilakukan di Fakultas MIPA Biologi Universitas Jember adalah rumput coklat (divisi Phaeophyta, jenis Padina gymnospora), rumput laut hijau (divisi Clorophyta, jenis Caulerpa racemosa var. occidentalis) dan rumput laut merah (divisi Rhodophyta Jenis Kappaphyrcus alvarezii) (gambar 1).

Total polisakarida dari rumput laut yang diekstrak dengan etanol dan air jumlah yang berbeda. Pada ekstrak air rumput laut coklat mempunyai kandungan polisakarida yang paling tinggi $(0,65)$ dibandingkan dengan yang lain, sedangkan untuk ekstrak etanol mempunyai total polisakarida yang rendah $(0,3)$. Rumput laut merah mampunyai kandungan rumput laut yang cukup tinggi $(0,8)$, pada eksrak etanol. Rumput laut hijau, dengan ekstrak air mempunyai total 
polisakarida yang lebih tinggi dibandingkan dengan ekstrak etanol. Rumput laut merah, hijau dan coklat mempunyai komposisi polisakarida yang berbeda (tabel 1).

DPPH digunakan sebagai substrat untuk mengevaluasi aktivitas antioksidan. Metode yang didasarkan pada pada pengurangan larutan DPPH etanol dengan adanya antioksidan yang menyumbangkan hidrogen, menghasilkan pembentukan bentuk nonradikal DPPH-H. Aktivitas scavenge DPPH radical dihitung berdasarkan persentasi pembentukannnya sebagai penghambatan terjadinya oksidasi. Aktivitas tertinggi terjadi pada ekstrak etanol rumput laut coklat dengan rata rata $58,951 \pm 1,148$ (table 2).

Tabel 1. Jumlah total polisakarida (g/2gr ekstraks) pada rumput laut.

\begin{tabular}{llll}
\hline & & Ekstraks air & Ekstrak etanol \\
\hline $\begin{array}{l}\text { Rumput } \\
\text { merah }\end{array}$ & laut & $0,3 \pm 0,54^{\mathrm{d}}$ & $0,8 \pm 1,32^{\mathrm{a}}$ \\
$\begin{array}{l}\text { Rumput } \\
\text { hijau }\end{array}$ & laut & $0,5 \pm 1,03^{\mathrm{b}}$ & $0,3 \pm 0,50^{\mathrm{d}}$ \\
$\begin{array}{l}\text { Rumput } \\
\text { coklat }\end{array}$ & laut & $0,65 \pm 2,0 \mathrm{c}$ & $0,3 \pm 0,45^{\mathrm{d}}$ \\
\hline
\end{tabular}

Data disajikan dalam rata rata \pm standar deviasi dengan uji anova (tingkat kepercayaan $p<0,05$ ) yang dilanjutkan dengan uji LSD. Huruf yang berbeda menunjukan perbedaan signifikansi. TD : Tidak terdeteksi

Tabel 2. Aktivitas antioksidan ekstraks etanol rumput laut dengan metode uji radikal DPPH (\% penghambatan) dengan konsentrasi $1 \mathrm{ml}$

\begin{tabular}{|c|c|c|}
\hline & \multicolumn{2}{|c|}{$\%$ penghambatan } \\
\hline & Ekstrak etanol & Ekstrak air \\
\hline $\begin{array}{l}\text { Rumput laut } \\
\text { merah }\end{array}$ & $7,696 \pm 0,339 a$ & $4,766 \pm 1,449 a$ \\
\hline $\begin{array}{l}\text { Rumput laut } \\
\text { hijau }\end{array}$ & $12,772 \pm 0,156^{b}$ & $20,334 \pm 2,56^{b}$ \\
\hline $\begin{array}{l}\text { Rumput laut } \\
\text { coklat }\end{array}$ & $58,951 \pm 1,148 c$ & $76,342 \pm 1,238 c$ \\
\hline
\end{tabular}

Data disajikan dalam rata ratatstandar deviasi dengan uji anova (tingkat kepercayaan $p<0,05$ ). Huruf yang berbeda menunjukan perbedaan signifikansi yang dilanjutkan dengan uji LSD.

\section{PEMBAHASAN}

Berdasarkan klasifikasi yang dilakukan di Laboratorium biologi, MIPA Univesitas Jember, rumput laut merah, hijau dan coklat berasal dari Budidaya oleh petani di perairan Jangkar Situbondo adalah rumput laut coklat divisi Phaeophyta, jenis Padina gymnospora, rumput laut hijau divisi Clorophyta, jenis Caulerpa racemosa var. occidentalis dan rumput laut merah divisi Rhodophyta jenis Kappaphyrcus alvarezii. Klasifikasi ini didasarkan pada pigmen yang menyusunnya, hasil fotosintesis yang dilakukannya. ${ }^{3}$ Rumput laut ini dikenal dengan alga laut atau makroalga laut. Rumput laut hidup terutama di habitat pesisir atau melekat pada batu/karang. Tumbuh di perairan pantai yang dangkal dan juga di wilayah laut dalam hingga kedalaman $180 \mathrm{~m} .{ }^{8}$ Pembagian rumput laut ini juga didasarkan pada kindomya yaitu kingdom Plantae termasuk Chlorophytas dikenal sebagai ganggang hijau dan Rhodophytas atau ganggang merah. ingdom Ochrophytas, sebagian besar diklasifikasikan dalam kelas Phaeophycea yaitu rumput laut coklat dan kingdom Protista, serta kingdom mikroalga. ${ }^{3}$ Rumput laut coklat biasanya besar terkadang disebut sebagai rumput laut raksasa yang panjangnya $20 \mathrm{~m}$, tebal seperti kulit dengan panjang 2-4 m, sampai spesies yang lebih kecil dengan panjang $30-60 \mathrm{~cm}$. Rumput laut merah biasanya lebih kecil, umumnya berkisar beberapa sentimeter hingga satu meter panjangnya. Rumput laut merah tidak selalu merah, terkadang berwarna ungu, bahkan merah kecoklatan, tetapi masih diklasifikasikan oleh para ahli botani sebagai Rhodophyceae karena karakteristik lain. Rumput laut hijau kecil, dengan kisaran ukuran mirip dengan rumput laut merah. ${ }^{12}$

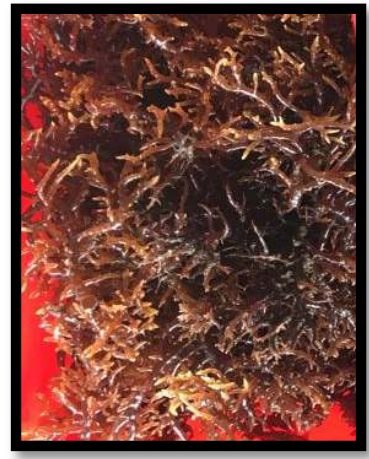

A

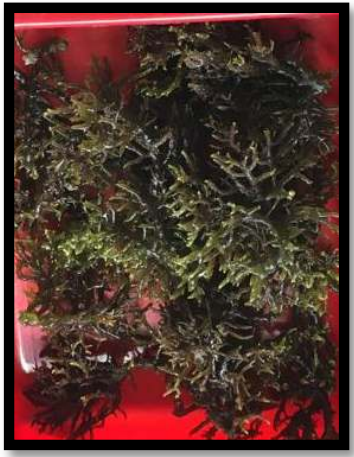

B

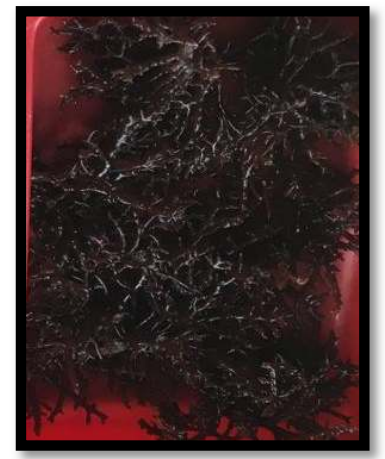

C

Gambar 1. Identifikasi rumput laut . A. Coklat (Padina gymnospora), B. Hijau (Caulerpa racemosa var. Occidentalis), C. Merah (Kappaphyrcus alvarezii) 
Chlorophylls a dan b merupakan pigmen utama sementara carotenoids adalah tambahan (asesori pigmen) dan keduanya terdistribusi disemua rumput laut. Di dalam alga hijau chlorophylls $a$ dan b mempunyai jumlah yang sama, seperti pada tumbuhan tingkat tinggi yang menghasilkan warna hijau. Xanthophyll pigment fucoxanthin sebagai accessory pigment disemua alga coklat, yang menutupi klorofil dan xanthophyl lainnya. Pada alga hijau phycoerythrin itu dominan dan bertanggung jawab pada pewarnaannya. ${ }^{13}$

Rumput laut merupakan salah satu sumber alami polisakarida dan menjadi komponen utama. Kandungan bahan bioactive, termasuk polisakarida dari masing masing ekstrak rumput laut air dan ethanol mempunyai konsentrasi yang berbeda secara signifikan. Sesuai hasil penelitian sebelumnya bahwa substrat (fase solid) dan pelarut (fase gerak) selama ekstraksi mempengaruhi kandungan bahan bioactive. Fase solid mempengaruhi rusak dan lisisnya dinding sel sitoplasma, koefisien difusi di dalam sel ke media ekstraksi, dan desorpsi dari dinding sel. ${ }^{8}$ Pengaruh pelarut juga tergantung pada polaritas bahan yang diekstrak dan pelarutnya, solubilitas yang diekstrak di dalam pelarut dan viskositas pelarut dan tensi permukaan. Semua fenomena tersebut dipengaruhi oleh waktu dan temperature. ${ }^{14}$ Polisakarida pada ekstrak air rumput laut coklat secara bermakna lebih tinggi dibandingkan pada ekstrak etanol oleh karena pengaruh bahan pelarutnya tersebut. Polisakarida pada rumput laut coklat yang terbanyak adalah Fucoidan yang merupakan bahan bioaktif utama yang ditemukan hanya di rumput laut coklat (Sargasum). Fucoidan merupakan polisakarida yang larut di dalam air terutama L-fucose dan sulfat dan juga beberapa glucuronic acid dan xylose walaupun jumlahnya sedikit. Oleh karena itu polisakarida pada rumput laut coklat menunjukan nilai yang tinggi pada ekstrak air. Akan tetapi struktur kimia fucoidans dari rumput laut coklat berbeda beda, hal itu dipengaruhi oleh tipe spesies, level maturasinya, lokasi geografi dan musim. ${ }^{15} \mathrm{Hal}$ ini memungkinkan konsentrasi polisakarida walaupun sama sama rumput laut coklat, akan berbeda dengan rumput laut coklat dengan spesies lain.

Ekstrak etanol rumput laut menunjukan kandungan polisakarida yang lebih sedikit terutama pada rumput laut coklat. Biasanya bioaktif polisakarida, berhubungan erat dengan sifat kimianya misalnya ukuran molekul, tipe dan rasio kandungan monosakarida serta gambaran glycosidic linkagesnya. Ekstraksi polisakarida menunjukan hasil yang lebih baik ketika menggunakan konsentrasi etanol yang rendah pada pelarutnya. Polisakarida dari rumput laut coklat biasanya diekstrak dengan multi step dan ekstraksi menggunakan media alkali ataupun kimia atau calcium klorida. Penggunaan kombinasi pelarut organic dan air lacetone
$70 \%$, methanol dan ethanol $80 \%$ ) dengan waktu yang lama, temperature tinggi dan penggunaan enzim berfungsi untuk merusak komponen dinding sel. ${ }^{14}$

Polisakarida dari rumput laut hijau dapat ditemukan pada Caulerpa (sulfated galacotans), Codium (sulfated arabinogalactans), Enteromorpha (ulvans), Monostroma (sulfated rhamnans), dan Ulva (ulvans). Struktur kimia polisakarida akan bervariasi dengan jenis spesies yang berbeda. Kandungan polisakarida dari ekstrak air rumput laut hijau Caulerpa terutama terdiri dari glucans dan heteropolisakarida yaitu galactose, glucose, mannose, and xylose. ${ }^{5}$ Akan tetapi polisakarida yang tertinggi dari spesies rumput laut hijau lain adalah ulvan. Ulvan dan rhamnant sulfate larut dalam air dengan $\mathrm{H}+$ membentuk hidrokoloid yang memiliki fungsi hidrasi yang baik. Ulvan dari Ulva armoricana dan Ulva rotundata menunjukan struktur kimia. Karakteristik makromolekul dan sifat reologi yang dipengaruhi oleh spesies dan musim. Tingginya berat molekul ulvan merupakan factor utama untuk terjadinya sifat geling. ${ }^{16}$ Polisakarida ulvan tersulfasi merupakan komponen dinding sel yang larut dalam air. Oleh karena itu ulvan efektif pada ekstrak menggunakan air. Beberapa penelitian menlaporkan bahwa ekstraksi menggunakan air panas menghasilkan hasil ekstraksi yang baik). ${ }^{17}$ Hasil penelitian tersebut sesuai dengan hasil penelitian ini bahwa rumput laut hijau yang diekstrak dengan air, mempunyai polisakarida lebih tinggi dibandingkan dengan ektraks etanol.

Hasil ekstrak polisakarida merupakan campuran kasar (crude mixture) dengan variasi berat molekul, komposisi monosakarida, kandungan sulfat apabila dilarutkan dalam air, terkadang juga ditemukan protein dan molekul yang berat molekulnya rendah. Campuran kasar itu selanjutnya dapat dipurifikasi menggunakan berbagai teknik termasuk etanol, membran pemisah, ionexchange, size-exclusion dan kromatografi. Presipitasi etanol selalu digunakan pada tahap pertama pada purifikasi polisakarida untuk menghilangkan senyawa dengan berat molekul rendah yang tidak diperlukan. ${ }^{6}$ Campuran kasar ini mempengaruhi aktivitas antioksidan pada ekstrak rumput laut. Tingginya konsentrasi polisakarida pada rumput laut pada hasil penelitian ini tidak tergantung pada tingginya konsentrasi polisakaridanya. Jenis polisakarida yang terektraski tidak ditentukan dalam penelitian ini, misalnya polisakarida yang tersulfasi atau tidak. Polisakarida yang tersulfasi yang berfungsi sebagai antioksidan. Selain itu di dalam ekstrak etanol dan juga air, memungkinkan juga adanya kandungan bahan bioactive lain, misalnya polifenol, flavonoid, bahan mineral dan juga kandungan pigmen dari masing masing rumput laut yang berfungsi pada aktivitas antioksidan. 
Kandungan antioksidan di dalam rumput laut sangat tinggi. Aktivitas antioksidan dari ekstrak rumput laut adalah polifenol, termasuk phlorotannins, sulfated polysaccharides (SPs), fucosterol, dan pigmen carotenoid misalnya fucoxanthin dan astaxanthin. Perbedaan kandungan bahan bioaktive dipengaruhi oleh lingkungan, paparan langsung sinar matahari dan juga plankton lain dilingkungannya. ${ }^{18}$ Free radikal bebas dihasilkan oleh sel-sel sebagai bagian dari fungsi normal selular, yang mempunyai peran penting pada patofisiologi beberapa penyakit misalnya kanker, alzheimer's, atherosclerosis dan beberapa toksisitas yang dihasilkan dari obat obatan. Free radikal bebas merupakan spesies yang sangat reaktif. Oksigen dalam proses fisiologisnya menghasilkan bahan yang reaktif tersebut yang disebut dengan reactive oxygen species (ROS). Oleh karena tidak berpasangan dan sangat reaktif, maka cenderung untuk mendonasikan atau menerima sebuah elekton. Free radikal bebas ini dapat menyerang makromolekul, termasuk lipid, protein dan DNA yang menyebabkan terjadinya kerusakan selulari" ${ }^{19}$ Antioksidan bertindak penyapu/pembersih radikal, donor hidrogen, donor elektron, peroxide decomposer, singlet oxygen quencher, enzyme inhibitor, synergist, dan metalchelating agents. Antioksidan enzim maupun non enzim yang terdapat di dalam lingkungan intraseluler maupun ekstraselular berfungsi untuk detoksifikasi ROS.20

Polisakarida rumput laut mempunyai aksi yang kuat dalam menghambat radikal bebas, sehingga dapat digunakan sebagai antioksidan yang berfungsi mencegah kerusakan jaringan. Aktifitas ini selain sulfasi pada molekulnya juga tergantung pada struktur cabangnya, berat molekul dan komposisi monosakaridanya. ${ }^{21}$ Beberapa penelitian menunjukan bahwa aktivitas antioksidan pada ekstrak air lebih tinggi dibandingkan dengan ekstrak etanol. ${ }^{17}$ Tingginya aktivitas antioksidan pada ekstrak air dikaitkan juga dengan beberapa bahan bioaktif yang terlarut dalam air, pada ekstrak air phlorotannin dan beberapa mineral akan terekspresi tinggi. Phlorotannin berpotensi besar dalam melawan DPPH, hydroxyl, superoxide, dan peroxyl radicals yang merupakan spesies reaktif radikal bebas.7,22 Senyawa bioaktif bersifat antioksidan apabila mampu menghambat agen oksidatif yang diproduksi Reactive Oxygen Spesies (ROS) oleh sel darah perifer. ${ }^{23}$ Rumput laut coklat memiliki senyawa fenolik dengan komponen struktural yang tidak terpisahkan dari dinding selnya yang juga berfungsi sebagai perlindungan dari radiasi UV, melakukan memproduksi alga kembali (reproduksi) dan memiliki mekanisme perlindungan terhadap faktor biotik dan bersifat terapeutik. Selain itu Sifat anti oksidan dari rumput laut adalah kandungan yang terdapat di dalamnya, misalnya adalah vitamin $C$, vitamin $E$, polyphenol tanaman, carotenoids, dan glutathione polifenol, vitamin, kandungan EPA dan DHA dll. 18 Komposisi bahan antioksidan dari rumput laut merah, coklat maupun hijau berbeda. Sifat antioksidan rumput laut ini di pengaruhi oleh komposisi bahan antioksidan yang terdapat dalam rumput laut. Beberapa penelitian menyebutkan bahwa kandungan protein rumput laut merah dan hijau lebih tinggi dibandingkan rumput laut coklat. Akan tetapi rumput laut coklat mempunyai kandungan bahan aktive lebih tinggi, misalnya vitamin $\mathrm{E}$ dan juga carenoid. Perbedaan polisakarida di dalam dinding sel rumput laut, mempengaruhi perbedaan komposisi kandungan di dalam setiap rumput laut. Komposisi itulah yang memepengaruhi level aktivitas antioksidannya.

Disimpulkan bahwa pada penelitian ini semua rumput laut mempunyai aktivitas antioksidan dengan tingkat yang berbeda. Rumput laut coklat memiliki aktivitas antioksidan lebih tinggi dibandingkan dengan yang lain. Hal ini dikaitkan dengan tingginya kandungan polivenol yang juga tinggi.

\section{UCAPAN TERIMAKASIH}

Terimakasih disampaikan kepada LP2M Universitas Jember yang telah mensuport dana pada penelitian ini. Kepada Dekan dan juga Wadek 1, FKG Unej, yang telah memfasilitasi dan memberikan dukungan pada penelitian ini. Kepada tim penelitian, anggota keris Biota Air, dan mahasiswa yang terlibat pada panelitian ini, disampaikan banyak terimakasih.

\section{DAFTAR PUSTAKA}

1. Holdt SL, Kraan S. Bioactive compounds in seaweed: Functional food applications and legislation. J Appl Phycol. $2011 ; 23(3): 543-97$.

2. Patel S. Therapeutic importance of sulfated polysaccharides from seaweeds: updating the recent findings. 3 Biotech. 2012;2(3):171-85.

3. Gomez-Zavaglia A, Prieto Lage MA, Jimenez-Lopez C, Mejuto JC, SimalGandara J. The potential of seaweeds as a source of functional ingredients of prebiotic and antioxidant value. Antioxidants. 2019;8(9).

4. Ma XT, Sun XY, YU K, Gui BS, Gui Q, Ouyang JM. Effect of Content of Sulfate Groups in Seaweed Polysaccharides on Antioxidant Activity and Repair Effect of Subcellular Organelles in Injured HK-2 Cells. Oxid Med Cell Longev. 2017;2017.

5. Drahansky M, Paridah M., Moradbak A, Mohamed A., Owolabi $F$ abdulwahab taiwo, Asniza $M$, et al. We are IntechOpen, the world's leading publisher of Open Access books Built by 
scientists, for scientists TOP $1 \%$. Intech. 2016;i(tourism):13.

6. XU SY, Huang X, Cheong KL. Recent advances in marine algae polysaccharides: Isolation, structure, and activities. Mar Drugs. 2017;15(12):1-16.

7. Chojnacka K. Biologically Active Compounds in Seaweed Extracts - the Prospects for the Application. Open Conf Proc J. 2012;3(1):20-8.

8. Khalid S, Abbas M, Saeed F, Bader-UI-Ain $\mathrm{H}$, Ansar Rasul Suleria $\mathrm{H}$. Therapeutic Potential of Seaweed Bioactive Compounds. Seaweed Biomater. 2018; (November).

9. Norra I, Aminah A, Suri R. Effects of drying methods, solvent extraction and particle size of Malaysian brown seaweed, Sargassum sp. on the total phenolic and free radical scavenging activity. Int Food Res J. 2016;23(4):1558-63.

10. Besednova N, Zaporozhets T, Kuznetsova T, Makarenkova I, Fedyanina L, Kryzhanovsky $S$, et al. Metabolites of seaweeds as potential agents for the prevention and therapy of influenza infection. Mar Drugs. 2019;17(6):1-21.

11. Hwang ES, Thi N Do. Effects of extraction and processing methods on antioxidant compound contents and radical scavenging activities of laver (Porphyra tenera). Prev Nutr Food Sci. 2014;19(1):408.

12. Cunha L, Grenha A. Sulfated seaweed polysaccharides as multifunctional materials in drug delivery applications. Mar Drugs. 2016;14(3).

13. Tanna B, Mishra A. Nutraceutical Potential of Seaweed Polysaccharides: Structure, Bioactivity, Safety, and Toxicity. Compr Rev Food Sci Food Saf. 2019;18(3):817-31.

14. Ferreira RM, Ribeiro AR, Patinha C, Silva AMS, Cardoso SM, Costa R. Water Extraction Kinetics of Bioactive Compounds of Fucus vesiculosus.
Molecules. 2019;24(18):1-15.

15. Langkawi $P$, Kaedah $K$, Fukoidan $P$, Hasil $T$, Fukosa K. EFFECT OF EXTRACTION METHODS ON THE YIELD, FUCOSE CONTENT AND PURITY OF FUCOIDAN FROM Sargassum sp. OBTAINED FROM PULAU LANGKAWI, MALAYSIA. Malaysian J Anal Sci. 2018;22(1):87-94.

16. Sun $\mathrm{C}$, Wu Z, Wang $\mathrm{Z}$, Zhang $\mathrm{H}$. Effect of ethanol/water solvents on phenolic profiles and antioxidant properties of Beijing propolis extracts. Evidence-based Complement Altern Med. 2015;2015.

17. Tariq A, Athar M, Ara J, Sultana V, Ehteshamul-Haque $S$, Ahmad $M$. Biochemical evaluation of antioxidant activity in extracts and polysaccharide fractions of seaweeds. Glob J Environ Sci Manag. 2015;1(1):47-62.

18. Bhattacharjee S, Islam GMR. Seaweed Antioxidants as Novel Ingredients. 2014;51 (August):215-33.

19. Nimse SB, Pal D. Free radicals, natural antioxidants, and their reaction mechanisms. RSC Adv. 2015;5(35):279868006 .

20. Lobo V, Patil A, Phatak A, Chandra N. Free radicals, antioxidants and functional foods: Impact on human health. Pharmacogn Rev. 2010;4(8):1 18-26.

21. He J, XU Y, Chen H, Sun P. Extraction, structural characterization, and potential antioxidant activity of the polysaccharides from four seaweeds. Int J Mol Sci. 2016;17(12).

22. Saraswati, Giriwono PE, Iskandriati D, Tan CP, Andarwulan N. Sargassum seaweed as a source of anti-inflammatory substances and the potential insight of the tropical species: A review. Mar Drugs. 2019;17(10):1-35.

23. Sinurat E, Maulida N. Effect of Fucoidan Hydrolysis on Its Activity as an Antioxidant. J Pascapanen dan Bioteknol Kelaut dan Perikan. 2018;13(2):123-30. 